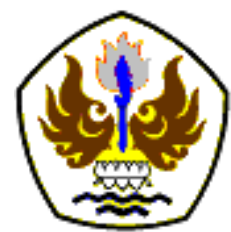

INFOMATEK

Volume 23 Nomor 1 Juni 2021

\title{
PENENTUAN UKURAN LOT PEMESANAN KEDELAI UNTUK MEMINIMUMKAN BIAYA PERSEDIAAN (STUDI KASUS DI RUMAH PRODUKSI TEMPE)
}

\author{
Akhsani Nur Amalia* \\ Program Studi Teknik Industri \\ Sekolah Tinggi Teknologi Wastukancana
}

\begin{abstract}
Abstrak: Penelitian dilakukan untuk mengetahui ukuran lot pemesanan kedelai sebagai bahan baku pembuatan tempe di Rumah Produksi Tempe. Studi kasus diambil berdasarkan pada penelitian yang dilakukan oleh Imelia Indriawan (2021). Hasil dari penelitian tersebut membuktikan bahwa dengan teknik Least Unit Cost, total biaya persediaan kedelai dapat berkurang sebesar Rp 108.000 atau sebesar 28,57\%. Akan tetapi, penelitian tersebut baru menggunakan satu teknik saja. Padahal, masih banyak teknik lot size yang dapat digunakan. Oleh karenanya, penelitian ini dilakukan untuk dapat mengetahui apakah LUC merupakan teknik penenuan ukuran lot terbaik yang menghasilkan total biaya persediaan paling minimum dibandingkan dengan teknik penentuan ukuran lot lainnya. Penelitian dilakukan dengan delapan teknik penentuan ukuran lot yaitu LFL, EOQ, POQ, LUC, LTC, SM, PPB dan WW. Hasil penelitian membuktikan bahwa teknik penentuan ukuran lot yang memberikan penghematan terbesar terhadap total biaya persediaan adalah Wagner Whitin Algorithm. Penghematan yang dapat dilakukan menggunakan teknik ini sebesar Rp 332.000 atau sebesar 29,61\%.
\end{abstract}

Kata kunci: Kedelai, Penentuan Ukuran Lot, Penghematan

\section{PENDAHULUAN}

\subsection{Latar Belakang}

Persediaan mencakup seluruh barang dan juga bahan dalam proses produksi maupun distribusi seperti bahan mentah, suku cadang, sub assembly dan produk jadi. Terdapat tiga komponen dalam biaya persediaan di antaranya biaya pesan, biaya simpan dan biaya kekurangan (Fogarty, dkk., 1991 [1]).

\footnotetext{
*) akhsani@stt-wastukancana.ac.id

Pertama diterima: 15 Maret 2021

Direvisi:5 April 2021

Disetujui untuk publikasi: 22 April 2021
}

Permintaan dependen adalah permintaan untuk barang-barang dengan level yang lebih rendah seperti, bahan baku, suku cadang dan sub assembly (Tersine, Richard J., 1994 [2]). Permintaan dependen terjadi secara kontinyu tergantung pada jumlah demand barang jadi yang akan diproduksi. Hal ini menyebabkan pentingnya sebuah pengendalian persediaan terhadap komponen-komponen dependen. Kelebihan komponen menyebabkan biaya persediaan tinggi. Akan tetapi, kekurangan komponen menyebabkan proses produksi terganggu. Oleh sebab itu, perlu perencanaan 
terhadap setiap komponen agar pemesanan yang dilakukan sesuai dengan yang dibutuhkan.

Perencanaan kebutuhan bahan baku dalam proses produksi adalah salah satu hal yang penting untuk keberlangsungan sebuah industri manufaktur. Perencanaan kebutuhan bahan baku dilakukan sepanjang periode perencanaan. Satuan periode yang digunakan dapat berupa tahun, bulan, minggu atau bahkan hari. Oleh karena sifatnya yang kontinyu, maka kebutuhan periode yang akan datang, bergantung pada ketersediaan periode sebelumnya

Penentuan ukuran lot adalah sebuah proses penentuan jumlah pesanan. Pesanan dilakukan ketika ada kebutuhan bersih yang bertanda positif. Jumlah unit yang dipesan sama nilainya dengan kebutuhan bersih di periode yang bersangkutan atau melebihi jumlah yang dibutuhkan agar memperoleh keuntungan ekonomis untuk memenuhi kebutuhan di periode berikutnya (Santoso, dkk., 2017 [3]). Penggunaan teknik penentuan ukuran lot akan berpengaruh terhadap besarnya biaya persediaan yang harus dikeluarkan oleh perusahaan. Umumnya, perusahaan menginginkan biaya persediaan yang minimum.

\subsection{Perumusan Penelitian}

Penelitian mengenai penentuan ukuran pemesanan bahan baku telah banyak dilakukan. Misalnya, penelitian yang dilakukan oleh Brillian A. R. Devy (2018) [4] yang bertujuan untuk menetapkan kebijakan dalam upaya pengendalian kebutuhan komponen pembuatan furniture, dimana biaya persediaan yang dikeluarkan menjadi acuan utama. Teknik penentuan ukuran lot yang digunakan adalah Silver Meal Algorithm dan Wagner Within. Hasil penelitian menunjukkan bahwa teknik penentuan ukuran lot terpilih untuk meminimumkan biaya adalah Silver Meal Algorithm, dimana teknik ini menghasilkan efisiensi biaya sebesar $3,2 \%$ sampai $4,5 \%$ dibandingkan kondisi awal. Penelitian yang sama dilakukan oleh Shinta Monica dan Putu Yudi Setiawan (2019) [5] yang bertujuan untuk mengetahui jumlah kebutuhan, biaya persediaan, waktu pemesanan dan teknik penentuan ukuran lot yang dapat menghasilkan biaya paling rendah untuk bahan baku produk Body Scrub Powder. Teknik penentuan ukuran lot yang digunakan adalah metode Lot for Lot dan Part Period Balancing. Hasil penelitian menunjukan bahwa teknik lot sizing terbaik adalah Part Period Balancing dengan biaya persediaan sebesar Rp 338.911,24.

Umumnya, penelitian untuk memperoleh biaya persediaan yang minimum dilakukan pada 
jumlah demand yang berubah untuk setiap periodenya, tergantung pada hasil peramalan. Pada penelitian Imelia Indriawan (2021) [6], demand kedelai bernilai konstan setiap periodenya. Penelitian dilakukan untuk menentukan ukuran lot pemesanan kedelai. Teknik penentuan ukuran lot yang digunakan adalah Least Unit Cost. Berdasarkan hasil penelitian tersebut, penghematan biaya persediaan yang dapat dilakukan sebesar $\mathrm{Rp}$ 108.000. Akan tetapi, pada penelitian tersebut baru dilakukan penentuan ukuran lot dengan menggunakan satu teknik saja, sehingga tidak dapat membandingkan teknik mana yang memiliki biaya paling minimum. Padahal banyak sekali teknik penentuan ukuran lot yang dapat digunakan. Oleh karenanya, penelitian ini bertujuan untuk mengetahui apakah Least Unit Cost merupakan teknik penentuan ukuran lot terbaik yang dapat menghasilkan total biaya persediaan yang paling minimum jika dibandingkan dengan teknik penentuan ukuran lot lainnya.

\subsection{Tujuan Penelitian}

Tujuan dari penelitian ini yaitu untuk mengetahui teknik penentuan ukuran lot terbaik untuk pemesanan kedelai dalam upaya meminimumkan biaya persediaan.

\section{METODOLOGI}

Penelitian dilakukan dengan beberapa tahap, seperti yang ditunjukan pada Gambar 1 .

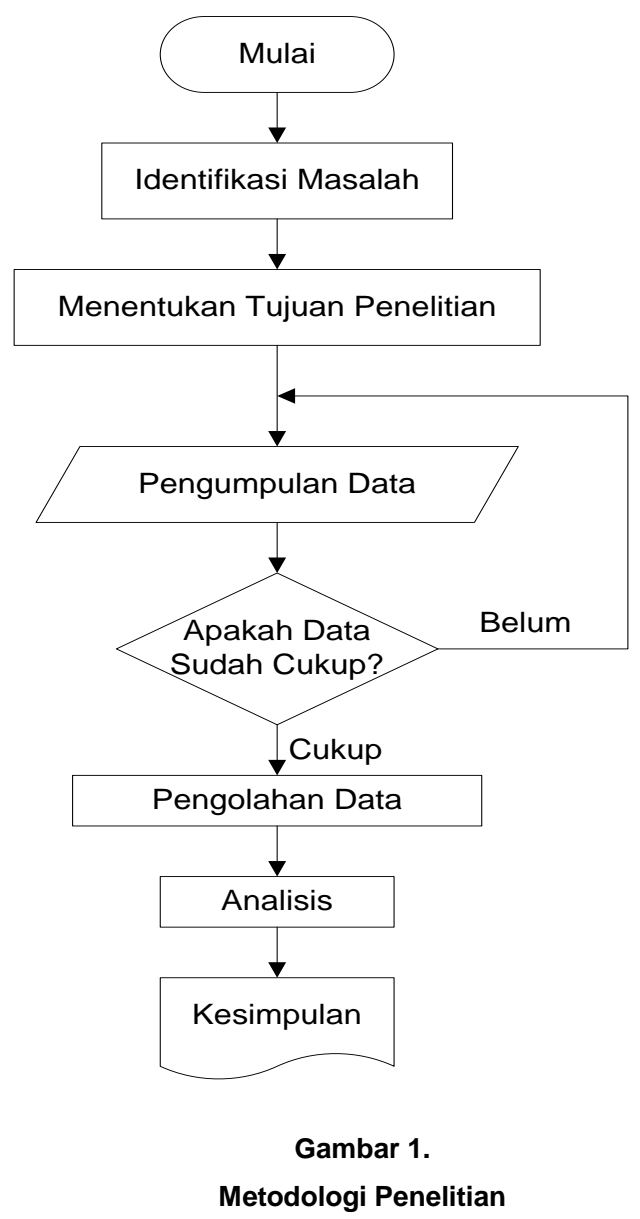

Tahap 1: Identifikasi Masalah

Identifikasi masalah dilakukan terhadap laporan penelitian yang ditulis oleh Imelia Indriawan (2021) [6] dengan judul Penentuan Ukuran Lot Pemesanan Kedelai di Rumah Produksi Tempe Menggunakan Metode Least Unit Cost (LUC). Demand kedelai konstan setiap periodenya, yaitu $100 \mathrm{~kg}$ per hari. Kapasitas penyimpanan dianggap cukup, sehingga mampu menampung berapapun kedelai yang disimpan. 


\section{Tahap 2: Pengumpulan Data}

Data dalam penelitian ini adalah data yang didapatkan dari penelitian sebelumnya, yaitu demand per hari, biaya simpan dan biaya pesan.

\section{Tahap 3: Pengolahan Data}

Pengolahan data dilakukan dengan delapan teknik penentuan ukuran lot berikut ini.

a. Lot for Lot (LFL)

Pada LFL, pesanan dijadwalkan untuk periode dimana terdapat permintaan. Jumlah bahan baku yang dipesan akan sama dengan jumlah bahan baku yang dibutuhkan. Oleh sebab itu, tidak ada barang yang disimpan [2].

b. Economic Order Quantity (EOQ)

EOQ merupakan model untuk pengendalian persediaan yang banyak digunakan. EOQ adalah teknik statistik yang menggunakan nilai rata - rata permintaan. EOQ dapat digunakan sebagai teknik penentuan ukuran lot ketika permintaan relatif konstan (Heizer, J., Barry R., 2014 [7])..

\section{c. Period Order Quantity (POQ)}

Period Order Quantity menetapkan jumlah permintaan selama periode tertentu yang akan dicakup oleh setiap pesanan. Logika POQ sama dengan EOQ. Akan tetapi, dalam $P O Q, E O Q$ dirubah menjadi satuan periode dalam bilangan bulat. Hasilnya berupa interval pesanan tetap, bukan ukuran pesanan tetap [2].

d. Least Unit Cost (LUC)

Least Unit Cost menentukan biaya rata rata per unit. Perintah replenishment direncanakan pada saat biaya rata - rata per unit meningkat untuk pertama kali. Periode replenishment dan prosedur diulang sampai ukuran lot diperoleh untuk keseluruhan waktu. Perintah replenishment biasanya direncanakan untuk periode pertama dengan persyaratan bernilai positif dan semua periode berikutnya dimana biaya rata-rata per periode pertama kali meningkat [2].

e. Least Total Cost (LTC)

Least Total Cost mencoba menyeimbangkan biaya simpan dan biaya pesan. Ukuran lot dimulai pada periode pertama, dilanjutkan pada periode berikutnya, menambahkan permintaan untuk periode tersebut pada lot jika kumulatif biaya simpan lebih kecil atau dekat dengan biaya pesan [3].

f. Silver Meal Algorithm (SM)

Silver Meal Algorithm merupakan biaya rata-rata per periode. Perintah replenishment direncanakan pada saat biaya rata-rata per periode pertama kali 
meningkat. Periode replenishment dan prosedur diulang sampai ukuran lot diperoleh untuk seluruh horizon waktu. Perintah replenishment biasanya direncanakan untuk periode pertama dengan persyaratan bersih positif dan semua periode berikutnya dimana biaya rata-rata per periode pertama kali meningkat [2].

\section{g. Part Period Balancing (PPB)}

Prosedur PPB mencoba menyeimbangkan biaya pesan dan biaya simpan menggunakan Economic Part Periods (EPP). EPP adalah rasio dari biaya pesan dan biaya simpan. Prosedur PPB mengkombinasikan kebutuhan hingga jumlah part periods hampir mendekati nilai EPP [3].

\section{h. Wagner Whitin Algorithm (WW)}

Wagner Whitin Algorithm adalah pendekatan dynamic programming yang bisa digunakan untuk menentukan kebijakan biaya minimal yang dapat dikontrol. Algoritma ini dapat digunakan untuk memperoleh solusi optimal untuk masalah penentuan ukuran pemesanan pada horizon waktu yang tertentu [2].

\section{ANALISIS DAN PEMBAHASAN}

Data demand yang digunakan adalah demand kedelai konstan 100 unit per hari dengan lead time satu hari. Penentuan ukuran pemesanan kedelai dihitung untuk periode tiga bulan. Biaya simpan sebesar Rp 50 per kg per hari dan biaya pesan sebesar Rp 13000 per sekali pesan.

Pengolahan data dilakukan menggunakan delapan teknik penentuan ukuran lot. Tabel 1 menunjukkan frekuensi pemesanan, jumlah kedelai yang disimpan dan biaya pesediaan selama tiga bulan perencanaan.

Tabel 1

Hasil Perhitungan Lot Size

\begin{tabular}{cccc}
\hline $\begin{array}{c}\text { Teknik } \\
\text { Lot } \\
\text { Size }\end{array}$ & $\begin{array}{c}\text { Frekuensi } \\
\text { Pemesanan }\end{array}$ & $\begin{array}{c}\text { Jumlah } \\
\text { Persediaan } \\
\text { (kg) }\end{array}$ & $\begin{array}{c}\text { Total Biaya } \\
\text { Persediaan } \\
\text { (Rp) }\end{array}$ \\
\hline LFL & 88 & 0 & 1144000 \\
\hline EOQ & 39 & 10128 & 1013400 \\
\hline POQ & 29 & 9000 & 827000 \\
\hline LUC & 44 & 4500 & 797000 \\
\hline LTC & 44 & 4500 & 797000 \\
\hline SM & 44 & 4500 & 797000 \\
\hline PPB & 29 & 9000 & 827000 \\
\hline WW & 43 & 4600 & 789000 \\
\hline
\end{tabular}

Analisis dilakukan terhadap biaya persediaan untuk masing-masing teknik penentuan ukuran lot. Berdasarkan hasil pengolahan data pada Tabel 1, biaya terendah diperoleh dari pengolahan menggunakan Wagner Whitin Algorithm dengan total biaya persediaan sebesar Rp 789.000. Jika dibandingkan dengan total biaya persediaan awal, besarnya penghematan yang dapat dilakukan adalah $\mathrm{Rp}$ 332.000 atau sebesar $29,61 \%$. 


\section{KESIMPULAN}

Setelah melakukan pegolahan data dan menganalisis hasilnya, diperoleh teknik penentuan ukuran lot terbaik untuk mendapatkan total biaya yang minimum yaitu Wagner Whitin Algorithm. Pemesanan kedelai dilakukan pada tanggal $5,7,9,11,13,15,17$, 19, 21, 23, 25 dan 27 di bulan Februari; tanggal 1, 3, 5, 7, 9, 11, 13, 15, 17, 19, 21, 23, 25, 27, 29 dan 31 di bulan Maret dan tanggal $2,4,6,8,10,12,14,16,18,20,22,24,26$ dan 28 di bulan April sebanyak 200 kg per sekali pesan. Penghematan biaya persediaan kedelai yang dapat dilakukan oleh perusahaan menggunakan teknik ini sebesar $29,61 \%$.

\section{DAFTAR PUSTAKA}

[1] Fogarty, D. W., dkk., Production \& Inventory Management, Ohio: SouthWestern Publishing Co., 1991.

[2] Tersine, R. J., Principles of Inventory and Materials Management, New Jersey: Prentice-Hall International, Inc., 1994.

[3] Santoso, Rainisa M. H., Perencanaan dan Pengendalian Produksi 1, Bandung: Alfabeta, 2017.
[4] Devy, B. A. R., "Penentuan Lot Size Pemesanan Bahan Baku Furniture Menggunakan Metode Dynamic Lot Sizing", 2018. Diakses tanggal 7 Maret 2021.

[5] Monica, S., Putu Y. S., "Analisis Material Requirement Planning Produk Body Scrub Powder Pada CV. Denara Duta Mandiri”, E-Jurnal Manajemen, Vol. 8, No. 5, 2019 : 2944-2972ISSN : 2302-8912, 2019. Diakses tanggal 7 Maret 2021.

[6] Indriawan, I., "Penentuan Ukuran Lot Pemesanan Kedelai di Rumah Produksi Tempe Menggunakan Metode Least Unit Cost (LUC)," Penelitian tidak diterbitkan. Program Sarjana STT Wastukancana, 2021.

[7] Heizer, J., Barry R., Operations Management Sustainability and Supply Chain Management, United States of America: Pearson Education Limited, 2014. 